\title{
Danuta Wiśniewska
}

UAM, Poznań

\section{CZY MILCZENIE ZAWSZE JEST ZLOTEM? PERCEPCJA CISZY \\ I MILCZENIA NA ZAJĘCIACH Z PRAKTYCZNEJ ZNAJOMOŚCI JĘZYKA ANGIELSKIEGO}

\section{Is silence always golden? Perception of silence in the EFL classroom}

\begin{abstract}
Formal foreign language teaching involves verbal and non-verbal interactions among the participants of language classes. The nature of these interactions may play a decisive role in the success or failure in language learning. The research described in this paper attempted to gain insight into students' perceptions of silence occurring during classroom language learning, to identify its causes and effects, and to appraise its potential value for learners.
\end{abstract}

\section{Wprowadzenie}

Truizmem jest stwierdzenie, że cisza oraz milczenie są konstruktami bardzo złożonymi, o których można dyskutować w obrębie różnych dyscyplin naukowych, między innymi takich jak socjologia, językoznawstwo, sztuka, psychologia, pedagogika. Jak pisze Bilmes (1994: 79), jest tyle rodzajów ciszy, ile jest rodzajów dźwięku. W tym miejscu zamierzam skoncentrować się na milczeniu/ciszy w kontekście zajęć z praktycznej znajomości języka obcego, na przykładzie zajęć z języka angielskiego, ze szczególnym uwzględnieniem znaczeń, jakie nadawane są różnym przejawom milczenia/ciszy przez uczestników tych zajęć. Posługuję się tutaj dwoma wyrazami: cisza i milczenie, w pewnych kontekstach używam ich zamiennie, korzystając z podejścia Jaworskiego (1997), który we wprowadzeniu do Silence. Interdisciplinary perspectives otwiera szeroka perspektywę pojmowania tego konceptu, począwszy od ciszy będącej brakiem jakiegokolwiek 
dźwięku do ciszy będącej brakiem mowy, czyli milczenia. Jednak w dalszej części artykułu, tam gdzie konieczne jest rozróżnienie między ciszą i milczeniem, dokonuję wyboru jednoznacznego terminu.

\section{Interakcja na zajęciach językowych}

Klasa szkolna, w której przebiega uczenie się języka obcego, uważana jest za dynamiczne, złożone środowisko, gdzie szczególną rolę odgrywa interakcja między nauczycielem i uczącymi się oraz pomiędzy uczącymi się, wpływając istotnie na proces nauczania i uczenia się (Ellis, 1999; Walsh, 2006). Ellis uważa, że uczenie się języka ma miejsce, kiedy biologicznie zdeterminowane funkcje mentalne ewoluują w kierunku bardziej złożonych funkcji właśnie poprzez interakcje społeczne, przebiegające za pomoca mowy. Nauczyciel i uczeń wchodzą $\mathrm{w}$ interakcje interpersonalne, oparte między innymi na zmianie tur w komunikowaniu się, spontaniczności i nieprzewidywalności. Interakcje te są wyraźnie ukierunkowane na osiagnięcie celu, jakim jest nauka języka. Podobnie znaczenie interakcji opartej na mowie postrzega Walsh (2002, 2006). Uczenie się języka obcego w klasie szkolnej zależy w dużym stopniu od świadomości nauczyciela co do związku między mową nauczyciela, interakcją i sposobnością uczenia się.

Interakcja w klasie szkolnej podlega uwarunkowaniom takim, jak i inne typy komunikacji interpersonalnej. Uważa się, że komunikacja między osobami zdeterminowana jest przez szereg czynników, takich jak sytuacja zewnętrzna (obiektywne cechy środowiska, w których przebiega interakcja), procesy poznawcze (percepcja siebie i partnera, co decyduje o doborze tematów, środków językowych), uwarunkowania społeczne i kulturowe (uwzględnienie kontekstu społecznego), motywacja, aparat anatomiczno-fizjologiczny, zmienne osobowościowe, cechy interakcji (specyfika kontaktu, poziom znajomości), stan emocjonalny (Nęcki, 1996: 136-138). Ponadto, nauczanie w środowisku zinstytucjonalizowanym, przynajmniej w tradycji zachodniej, nacechowane jest prymarnościa mowy, dominacją komunikacji werbalnej (wokalnej), aczkolwiek różne jej formy mogą mieć większe lub mniejsze znaczenie (Ollin, 2008). W nauczaniu tradycyjnym większą część czasu zajmuje monolog nauczyciela, natomiast uczniowie odzywają się w momentach przez niego wyznaczonych. Znacznie rzadziej inicjatorem komunikacji są uczniowie, chociaż większa swoboda w tym względzie panuje podczas mniej konwencjonalnych form pracy, takich jak praca w parach czy praca grupowa. Również wiek uczniów oraz poziom kompetencji językowej może wpływać na kształtowanie się komunikacji interpersonalnej w klasie. Jednak nie wszystkie fazy zajęć językowych, jak pokazuje obserwacja, nacechowane są komunikacją werbalna/wokalną. Momenty ciszy mogą pojawiać się w trakcie zadań, których wykonanie nie wymaga mówienia, część osób może milczeć, gdy inni mówią, milczenie może być reakcją na zachowanie nauczyciela lub innych uczniów. Czasem nauczyciel steruje fazami ciszy i mówienia, innym razem panowanie nad tymi elementami interakcji klasowej wymyka się spod jego kontroli. 
Również wymagania nauczycieli w tym względzie są zróżnicowane, z jednej strony oczekują ciszy, która pozwoliłaby na niezakłócony przebieg interakcji w klasie, z drugiej strony uczniowie, którzy nie partycypują werbalnie w zajęciach postrzegani są jako pasywni, nie włączający się aktywnie w proces uczenia się, tym samym często jako gorsi. Takie postrzeganie „cichych” uczniów może być obecne zwłaszcza na zajęciach językowych, które zmierzają do rozwoju kompetencji komunikacyjnych, a także w świetle obecnych trendów edukacyjnych, które oczekują od osoby uczącej się jak największego zaangażowania, również werbalnego (Jaworski i Sachdev, 2004). Potwierdzaja to badania prowadzone przez Jaworskiego i Sachdeva (2004) na podstawie komentarzy pisanych przez nauczycieli oceniających aplikantów do uniwersytetu. Wszelkie odniesienia do milczenia ucznia były formułowane negatywnie. Co ciekawe, jeśli komentarz dotyczył umiejętności akademickich, był zdecydowanie negatywny, natomiast w przypadku odniesień do osobowości ucznia, był bardziej pozytywny. Takie wyniki badania odzwierciedlają oczekiwania nauczycieli, aczkolwiek, jak zauważaja autorzy, nie ma badań, które potwierdzałyby pozytywną korelację między mową czy rozmownością ucznia a jego osiągnięciami w nauce.

Milczenie lub nawet tylko zwlekanie z odpowiedzią na pytanie stanowi pewne zagrożenie dla integralności rozmowy, zwłaszcza jeśli jest prowadzona przez osoby nie pozostające w bliskiej zażyłości (Heydon, 2011). Cisza, wynikająca z braku werbalnej partycypacji uczniów w zajęciach, nie jest pożądana, często też wywołuje zakłopotanie nauczyciela. Uważa się, że czas milczenia dłuższy niż jedna-dwie sekundy stanowi o zakłóceniu komunikacji i jest informacją o pewnych formach oporu (Nęcki, 1996). W ten sposób, między innymi, uczestnik komunikacji ma możliwość przekazywania swojej reakcji na wypowiedź nadawcy. Wzrost zainteresowania milczeniem, zwłaszcza w latach 80. i 90. ubiegłego stulecia, sprawił, że dostrzeżono jego miejsce i rolę w komunikacji interpersonalnej jako niezwykle bogatego środka wyrazu.

Zdolność rozumienia procesów zachodzących podczas interakcji między uczestnikami sytuacji uczeniowej jest kluczowa, by nauczyciel mógł zapewnić odpowiednie warunki do uczenia się (Walsh, 2002). Problematyka relacji mowy, interakcji społecznych i uczenia się jest obszernie omawiana w literaturze przedmiotu, natomiast brakuje dyskusji na temat związku między interakcja, uczeniem się języka obcego oraz ciszą i milczeniem, dlatego potrzebne są badania, które pogłębią nasze rozumienie relacji milczenia/ciszy z uczeniem się języka obcego i interakcjami w klasie szkolnej. W dalszej części artykułu najpierw zostaną omówione pojęcia ciszy/milczenia oraz funkcje, jakie spełniają w komunikacji, ze szczególnym uwzględnieniem ich znaczenia w interakcji klasowej. Następnie zostanie omówione badanie przeprowadzone ze studentami filologii angielskiej, którego głównym celem było stwierdzenie, w jaki sposób cisza i milczenie postrzegane są przez uczestników zajęć języka obcego. 


\section{Cisza - milczenie}

Cisza jest pojęciem niezwykle zróżnicowanym, pojemnym i trudno przedstawić jedna wspólną wszystkim odcieniom znaczeniowym definicję. Jak wylicza Jaworski (1997: 3-4), pojęcie ciszy może obejmować sygnał słuchowy, pauzę, unikanie słów taboo, może stanowić narzędzie manipulacji, postawę słuchacza, może wyrażać idee artystyczne, może mieć charakter językowy, wizualny, kinetyczny, i wiele innych, jest tym samym bogatym środkiem wyrazu. Pojęcie ciszy obejmuje więc całe spektrum znaczeń, od ciszy rozumianej w kategoriach akustycznych (jako brak dźwięków, ten stan Bilmes (1994: 79) nazywa ciszą absolutna) do względnej nieobecności dźwięku, np. w sytuacji nieobecności mowy, kiedy to mamy do czynienia z ciszą konwersacyjną (Bilmes, 1994: 79). Cisza konwersacyjna, jako element komunikacji wybierany przez nadawcę, by się wyrazić, jest milczeniem, natomiast brak dźwięku, stan zewnętrzny w stosunku do interakcji, pozostaje ciszą (Ephratt, 2008: 1911). Milczenie ma charakter komunikatywny, jest celowo podejmowane $\mathrm{w}$ sytuacji postrzeganej przez obydwie strony jako komunikatywna oraz cechuje je wolicjonalność, teleologiczność, substytutywność i kontekstualność (Sobkowiak, 1997: 44). Kurzon (1998: 25) uznaje milczenie za akt mowny, wynikający z decyzji osoby do pozostania milczaca, jednakże przyznaje także, że milczenie w pewnych sytuacjach może nie mieć charakteru wolicjonalnego. Milczenie nabiera znaczenia tylko w konkretnym werbalnym lub niewerbalnym kontekście (Sobkowiak, 1997: 44), może mieć zarówno pozytywne, jak i negatywne konsekwencje dla sytuacji społecznej, może łączyć lub dzielić (Sobkowiak, 1997: 46).

Nakane (2007) rozpatruje milczenie na różnych poziomach, od najbardziej szerokiego, tzn. milczenia będącego powstrzymywaniem się od mówienia w akcie komunikacyjnym, np. milczenie w czasie ceremonii, milczenie w klasie aż do znacznie krótszych sytuacji, takich jak pauzy, które następuja po zakończeniu tury, gdy nikt nie zabiera głosu oraz pauzy powstające w trakcie wypowiedzi. Milczenie w czasie ceremonii lub obrzędów jest przykładem na to, że nawet całe zdarzenie komunikacyjne może przebiegać bez słów. Seville-Troike (1985) wymienia szereg takich kontekstów instytucjonalnych, które charakteryzuje cisza, m.in. biblioteki, nabożeństwa, pogrzeby, procedury prawne, przedstawienia operowe, sala kinowa. Nakane (2007: 11-12) w swojej dyskusji stwierdza, że milczenie może mieć tyle funkcji co mowa; są to funkcja kognitywna (pauzy, wahania), funkcja dyskursywna (wyznaczanie granic wypowiedzi), funkcja społeczna (negocjowanie i utrzymywanie dystansu społecznego, wywoływanie wrażenia, negocjowanie i utrzymywanie kontroli, strategia grzecznościowa) i funkcja afektywna. Jak już wspomnieliśmy, milczenie ma nie tylko charakter intencjonalny. Milczenie nieintencjonalne wynika często z uwarunkowań psychologiczno-społecznych. Osoba może nie odpowiadać, czy nie włączać się do rozmowy, ponieważ jest nieśmiała, czuje się zakłopotana, ma problemy z mówieniem natury fizjologicznej. 
Milczenie klasyfikowane jest jako kategoria paralingwistyczna w kontekście komunikacji niewerbalnej (Ephratt, 2011) i niewokalnej, stanowi niezwykle istotny czynnik w komunikacji międzyludzkiej (Jensen, 1973) oraz podlega znacznemu wpływowi środowiska, w którym komunikacja przebiega (Malandro i Barker, 1983). Od czasu większego zainteresowania milczeniem podejmowano też próby rozróżniania między jego poszczególnymi typami. Jedna z wcześniejszych prób (Bruneau, 1973) ujawnia trzy formy milczenia: psychologiczna, interaktywną oraz społeczno-kulturowa. Milczenie psychologiczne jest krótkotrwałe, stanowi raczej moment zawahania lub celowego spowolnienia, aby słuchacz mógł nadążyć za wypowiedzia, zawiera powtórzenia, czasem niekompletne zdania. Milczenie interaktywne trwa zazwyczaj dłużej i związane jest z relacjami między nadawcą i odbiorcą oraz przejmowaniem tury w komunikacji. Milczenie socjokulturowe wynika ze społecznego i kulturowego podłoża komunikacji. Każde z tych znaczeń milczenia może potencjalnie pojawić się również w klasie szkolnej podczas zajęć z praktycznej nauki języka obcego.

Kurzon (2007) rozróżnia cztery typy milczenia. Pierwszy, określony jako milczenie konwersacyjne, będący często przedmiotem analizy dyskursu, odnosi się do takich zachowań jak brak odpowiedzi na pytanie lub nieuczestniczenie w dyskusji. O tym typie milczenia mówi się głównie w kontekście rozmowy między dwoma partnerami. Kurzon rozróżnia między milczeniem, co do którego decyzję podejmuje uczestnik interakcji i takim, które narzuca sytuacja lub na przykład konwenanse, choć oczywiście nie zawsze można tak czytelnie rozróżnić między tymi typami. Milczenie nieintencjonalne może być wywołane zahamowaniami natury psychologicznej: boję się, wstydzę itp. Dość blisko związane z milczeniem konwersacyjnym jest milczenie tematyczne, które powstaje w momencie, gdy mówiący w rozmowie milczy na któryś z poruszanych tematów. Milczenie tematyczne ma raczej charakter intencjonalny, a decyzja o milczeniu na dany temat pochodzi z woli osoby partycypującej w rozmowie. Istotną cechą tego milczenia jest również brak relacji czasowej, można bowiem milczeć na dany temat nie przerywając mówienia. Odrębną kategorię stanowi milczenie związane z cichym czytaniem tekstu. Wówczas może ono wynikać z woli czytającego lub być narzucone na przykład przez nauczyciela polecającego uczniom w ciszy przeczytać jakiś tekst. Ciche czytanie może mieć charakter indywidualnego zajęcia bez towarzystwa innych, lub odbywać się w grupie osób, np. w klasie, kościele, bibliotece. W tej kategorii milczenie może być intencjonalne albo niezamierzone. I w końcu milczenie sytuacyjne, mające $z$ reguły charakter zinstytucjonalizowany, np. w sadach, szpitalach, więzieniach, w czasie publicznych ceremonii. Według Kurzona, cechy, które sa pomocne w określaniu charakteru milczenia to relacja między partnerami interakcji, liczba zaangażowanych osób, obecność tekstu, intencjonalność, normy społeczne, obecność osoby milczącej.

Johannesen (1974) zwraca uwagę na konteksty, w jakich milczenie może wystapić. Wymienia tutaj procesy myślowe i kulturowe, codzienną komunikację interpersonalna, życie polityczne i obywatelskie, oraz konteksty związane z patologiami, 
takie jak poradnictwo, psychoterapia. Ponadto wymienia dwadzieścia różnych znaczeń milczenia. Warto je w tym miejscu przytoczyć dla zilustrowania bogactwa znaczeniowego zawartego w akcie milczenia. Tak więc milczenie może oznaczać, że:

(1) Osoba nie posiada wystarczających informacji, aby rozmawiać na dany temat.

(2) Osoba nie ma poczucia konieczności mówienia. (3) Osoba starannie rozważa, co dokładnie powiedzieć. (4) Milczenie może po prostu odzwierciedlać normalny rytm myślenia osoby. (5) Osoba unika dyskusji na kontrowersyjny lub drażliwy temat ze strachu. (7) Milczenie wyraża zgodę. (8) Osoba jest wattpiąca lub niezdecydowana. (9) Osoba jest znudzona. (10) Osoba jest niepewna co do znaczenia wypowiedzi innej osoby. (11) Osoba odczuwa respekt, lub słucha z wytężoną uwaga, lub jest ogarnięta jakimś uczuciem. (12) Osoba zadziera nosa lub jest niegrzeczna. (13) Milczenie jest środkiem ukarania innej osoby, unicestwienia innych symbolicznie poprzez wyłączenie ich z komunikacji werbalnej. (14) Milczenie osoby zaznacza charakterystyczne zaburzenie osobowościowe. (15) Osoba czuje, że nie potrafi się wysłowić, mimo chęci komunikowania; być może temat bardziej nadaje się do wyczucia intuicyjnego aniżeli do dyskusji werbalnej. (16) Milczenie odzwierciedla troskę, by nie urazić innej osoby. (17) Osoba śni na jawie lub zajęta jest innymi sprawami. (18) Osoba używa milczenia, by wzmocnić swoją izolację, niezależność i poczucie wyjątkowości. (19) Milczenie oznacza ponury gniew. (20) Milczenie osoby odzwierciedla empatię, podzielanie nastroju lub spostrzeżenia (Johannesen, 1974: 29) ${ }^{1}$.

\section{Wcześniejsze badania milczenia w klasie językowej}

Od momentu uznania ciszy i milczenia za istotne i bogate znaczeniowo elementy komunikacji znacznie wzrosło zainteresowanie tymi pojęciami i ilość badań prowadzonych w różnych kierunkach, między innymi przedmiotem zainteresowań jest milczenie w odmiennych kontekstach kulturowych, zarówno makro jak i mikro, związane ze specyfiką kulturową danej narodowości lub sytuacji (np. proces sądowy, milczenie zakonne), milczenie w nawiązaniu do różnic genderowych, milczenie uczniów i nauczycieli. W odniesieniu do tego ostatniego zakresu, należy zwrócić uwage na badania Jaworskiego i Sachdeva (1998, 2004), które dotyczyły przekonań i postaw nauczycieli i studentów na temat milczenia w klasie, które do tej pory nie było znaczącym przedmiotem badań. Część wcześniejszych badań dotyczyła milczenia w kontekście wielojęzyczności i wieloetniczności, jak również sprawowania kontroli nad klasą za pomocą milczenia (krótki przegląd tych badań w Jaworski i Sachdev, 1998). Badania Jaworskiego i Sachdeva koncentrują się przede wszystkim na wartościowaniu ciszy i milczenia w procesie edukacyjnym, z uwzględnieniem kontekstu społeczno-kulturowego szkół, w których zostało przeprowadzone badanie oraz różnicy płci. Zdecydowanie niewiele badań dotyczy ciszy i milczenia nauczycieli i uczniów języków

1 Tłumaczenie tekstu własne. 
obcych. Ollin (2008) przeprowadziła badanie na temat ciszy w klasie szkolnej wśród 25 wykwalifikowanych nauczycieli różnych przedmiotów, między innymi również języka angielskiego jako drugiego. Badanie zostało przeprowadzone w tradycji jakościowej, z wykorzystaniem trójfazowych wywiadów, zaczynając od bardziej ustrukturyzowanej formy do otwartego dialogu. W wywiadach autorka próbowała rozróżnić między percepcją ciszy w życiu codziennym nauczycieli oraz podczas prowadzonych lekcji w szkołach średnich i podstawowych. Podczas badania pytano o typy ciszy, asocjacje związane z ciszą, świadome stosowanie ciszy na lekcji, dźwięki kojarzone pozytywnie i negatywnie z ciszą. Na podstawie zebranego obszernego materiału autorka ustaliła przede wszystkim podstawowe rozróżnienie czynione przez nauczycieli między ciszą w ich życiu poza szkołą i w szkole. Cisza poza szkołą była traktowana jako cisza przeznaczona dla danej osoby, jej prywatna cisza, natomiast w szkole cisza, według respondentów, służy uczniom i wspomaga proces uczenia się. Nauczyciele stwarzają momenty ciszy, aby pozwolić uczniom zrelaksować się, uspokoić grupę, zdyscyplinować, ukierunkować myślenie, dać czas na zastanowienie się. Cisza stwarza przestrzeń wolną od myśli innych. Różne są również konfiguracje ciszy, milczenie może zachowywać nauczyciel lub uczniowie lub obie strony. W każdym przypadku cisza będzie miała inne znaczenie i inną funkcję. Nauczyciele zwracali również uwagę na różnorodność typów ciszy, np. cisza wizualna, przestrzenna. Nauczycielka języka angielskiego jako obcego wykazywała szczególne wyczulenie na kwestię ciszy, jako element konieczny, by stworzyć uczniom możliwość mówienia. Według nauczycieli milczenie uczniów nie zawsze oznacza brak partycypacji, ponadto niektóre z zajęć lekcyjnych wymagają ciszy.

Tatar (2005) przeprowadziła z kolei badanie dotyczace ciszy z perspektywy czterech studentów nie anglojęzycznych przebywających na uniwersytecie w Stanach Zjednoczonych. Badanie również miało charakter jakościowy; wykorzystując retrospektywne wypowiedzi w trakcie szeregu wywiadów, obserwacje zajęć, analizę dokumentów autorka podjęła próbę odpowiedzi na pytania o doświadczenia milczenia studentów. Zebrane dane pozwoliły autorce ustalić następujące funkcje ciszy: strategia zachowania twarzy, rodzaj uczestnictwa w zajęciach, reakcja na udział innych, przejaw respektu dla innych, wyraz poczucia nieumiejętności wypowiedzenia się (Tatar, 2005: 288). Autorka konkluduje, że milczenie studentów nie zawsze miało charakter negatywny, czasami było świadomie wybraną strategia w sytuacji konfrontacji ze studentami anglojęzycznymi.

Interesujące wyniki przynosi badanie Harumi (2011) przeprowadzone wśród 197 studentów w Japonii dotyczące ciszy na zajęciach z języka angielskiego. Za pomocą kwestionariusza zebrano dane na ten temat od studentów oraz od prowadzących zajęcia, zarówno Japończyków, jak i rodzimych użytkowników języka angielskiego. Celem ankiety było zidentyfikowanie, w jaki sposób postrzegają ciszę studenci, ponadto porównanie poglądów studentów i nauczycieli oraz stwierdzenie, w jaki sposób nauczyciele mogą zmniejszać powstające napięcia. Ogólne kategorie wyodrębnione na podstawie analizy danych są podobne 
dla nauczycieli i dla studentów, jednakże studenci podają bardziej szczegółowo przykłady dla każdej z tych kategorii. Ogólnie rzecz biorąc cisza wynika z problemów językowych, braku dostatecznej ilości czasu do zastanowienia, problemów natury psychologicznej oraz problemów z przejmowaniem tury.

Klasa szkolna jest specyficznym środowiskiem, w którym dystrybucja mowy i milczenia naznaczona jest specyfika kontekstu (Seville-Troike, 1985). Jest to miejsce, w którym pewne formy stosowania ciszy i milczenia są akceptowane i pożądane, a inne nie, miejsce, w którym cisza może odgrywać rolę facylitatywną, jak i rolę negatywną (Jaworski i Sachdev, 1998). Stąd wydaje się, że potrzebne jest badanie milczenia i ciszy w różnych kontekstach edukacyjnych, a wyniki tych badań moga być pomocne nauczycielom w interpretowaniu sytuacji komunikacyjnych w klasie, a tym samym ułatwić nauczycielom kierowanie procesem uczenia się i nauczania. Klasa językowa jest szczególnie ciekawym środowiskiem w tym względzie, ponieważ tutaj komunikacja między nauczycielem i uczniami oraz między uczniami (przebiegająca zarówno w języku rodzimym, jak i nauczanym) służy nauczeniu się komunikowania w języku obcym, a więc rozumienie, co możemy „powiedzieć” oraz co możemy „zyskać” lub „stracić” poprzez milczenie jest ważne i dla nauczycieli i dla uczniów. Opisane poniżej badanie miało na celu pozyskanie wstępnego oglądu ciszy i milczenia w jednorodnym językowo środowisku polskich studentów uczących się języka angielskiego jako języka obcego.

\section{Badanie: cel, metoda, uczestnicy}

Celem badania przedstawionego w niniejszym artykule było rozpoznanie, w jaki sposób studenci postrzegają ciszę i milczenie, które mają miejsce na zajęciach z praktycznej nauki języka angielskiego. Cisza, na potrzeby tego badania, jest rozumiana jako milczenie wszystkich osób obecnych na zajęciach, jest to więc milczenie kolektywne. Natomiast jeśli pytania i odpowiedzi dotyczą tylko jednego respondenta, wówczas mowa jest o milczeniu. By uzyskać wgląd w naturę milczenia na zajęciach z praktycznej nauki języka obcego, postawiono następujące pytania badawcze:

1. W jakich sytuacjach na zajęciach panuje cisza?

2. W jakich sytuacjach studenci zachowuja milczenie?

3. Jaki jest wpływ ciszy i milczenia na studentów i zajęcia?

W badaniu wzięło udział 94 studentów filologii angielskiej, od 1 do 3 roku, zarówno studiów dziennych, jak i zaocznych, licencjackich jednego z uniwersytetów.

Celem badania było uzyskanie informacji na temat percepcji ciszy przez studentów, w związku z czym dane zostały zebrane bezpośrednio od nich za pomocą kwestionariuszy ankiet zawierających 8 pytań otwartych oraz trzy zadania stymulujące do refleksji nad przedmiotem badania. Pytania od 1 do 6 nie sugerowały żadnych typów ciszy i milczenia. Ich zadaniem było raczej pozyskanie danych na ten temat od uczestników badania i rozpoznanie, które z typów 
ciszy/milczenia zostaną określone przez studentów. W pierwszym punkcie ankiety respondenci proszeni byli o wypisanie najważniejszych skojarzeń dotyczących pojęcia ciszy w kontekście zajęć z języka angielskiego. Celem tego polecenia było uzyskanie jak najszerszego, nie ograniczonego żadnymi ramami, wachlarza odpowiedzi. Pytanie drugie bezpośrednio odnosiło się do sytuacji, w których na zajęciach zapada cisza, natomiast trzecie i czwarte pytanie dotyczyły wpływu ciszy na uczestników zajęć i na same zajęcia. Następne pytanie dotyczyło bezpośrednio respondentów i odnosiło się do sytuacji, w których oni sami nie zabieraja głosu na zajęciach, w ten sposób współtworząc ciszę. Dwa kolejne pytania dotyczyły ciszy, która jest potrzebna na zajęciach i jej wpływu na uczestników zajęć i zajęcia. Pozostałe trzy pytania koncentrowały się na osobistych doświadczeniach i refleksji studentów na temat ciszy. Wszystkie pytania i zadania w ankiecie miały charakter otwarty, umożliwiając respondentom swobodna wypowiedź. Odpowiedzi uzyskane na poszczególne pytania ankiety były porównywane i zostały zanalizowane w odniesieniu do pytań badawczych.

\section{Wyniki badania}

W tej części artykułu omówione zostaną trzy problemy związane z ciszą i milczeniem na zajęciach, które zostały wyłonione w trakcie analizy danych. W pierwszej sekcji zostaną omówione wyniki analizy sytuacji generujących ciszę na zajęciach, czyli sytuacji, gdy nikt ze studentów nie zabiera głosu przy jednoczesnym milczeniu prowadzącego. Sekcja druga zawiera przedstawienie sytuacji, w których poszczególne osoby milczą, przy czym możliwe jest, że inne zabieraja głos. Próba określenia wpływu ciszy (milczenia kolektywnego) na uczestników zajęć oraz na uczenie się języka obcego zostanie zaprezentowana na podstawie otrzymanych wyników w sekcji trzeciej.

\subsection{Sytuacje generujące ciszę na zajęciach}

Studenci wymienili ponad 100 różnych sytuacji, w których według nich pojawia się cisza, tym samym ukazując wieloaspektowość pojęcia. Sytuacje wyszczególnione przez respondentów można sprowadzić do kilku bardziej ogólnych kategorii. Najczęściej wymienianymi sytuacjami, w których na zajęciach panuje cisza, były zadania wymagające koncentracji ze strony osób uczących się, takie jak pisanie testu, indywidualne wykonywanie zadań, czytanie tekstu, pisanie. W tych sytuacjach cisza stanowi naturalny i często konieczny kontekst, ułatwiający procesy uczenia się, w którym mowa innych mogłaby stanowić, przynajmniej dla części uczących się, istotną przeszkodę. Do tego rodzaju ciszy wrócimy jeszcze omawiając pytanie o ciszę pożądaną.

Druga, co do częstotliwości pojawiania się, sytuacja to brak wiedzy lub nieznajomość odpowiedzi na pytanie, co uniemożliwia wypowiadanie się, zabieranie głosu na zajęciach. 
Pozostałe sytuacje, w których zapada cisza były wymieniane rzadziej, ale zostały jednak dość wyraźnie artykułowane przez respondentów. Tutaj, do najważniejszych czynników powodujących ciszę, zaliczono różne odcienie strachu: strach przed krytyką nauczyciela, strach przed publicznym wypowiadaniem się, strach przed wywołaniem do odpowiedzi, obawa przed porażka. Innymi uczuciami pojawiającymi się w wypowiedziach były nieśmiałość, zakłopotanie, wstyd. Często wskazywano na stres, jako czynnik wywołujący ciszę, bez precyzowania, czego ten stres dotyczy lub z czego wynika. Wymieniono również szereg sytuacji, które przyczyniają się do powstawania ciszy. Do takich sytuacji należą nieporozumienia między nauczycielem a uczącymi się, brak reakcji studentów na zadane pytanie, niezręczne sytuacje, nuda, niezrozumienie intencji wykładowcy, nieprzygotowanie studentów do zajęć, napięta atmosfera, zbyt trudny lub zbyt łatwy materiał, nieodpowiednia atmosfera, wywołana nieprzyjazną postawą wykładowcy, zajęcia nie lubiane ze względu na ich przedmiot lub postawę wykładowcy, pytania niezręczne lub zbyt osobiste.

Cisza na zajęciach może także wynikać z pewnych postaw studentów, gdyż dość często przyczyn ciszy upatrywali w braku zaangażowania w zajęcia, braku zainteresowania tematyką, znudzeniu. Niektórzy z respondentów uważali, że brak zdania na dany temat powstrzymuje ich od zabierania głosu. Inni wymieniali niechęć do odpowiadania, niechęć do interakcji, i ogólną niechęć do nauki. Przyczyną ciszy w klasie może też być osobowość i postawa wykładowcy. W tym przypadku wymieniono takie cechy jak groźny, zdenerwowany, wymagający, zniechęcający do nauki. I w końcu, wśród sytuacji powodujących ciszę znalazły się powody natury fizycznej, jak pora dnia oraz senność i zmęczenie. Ciszę moga też generować sytuacje pozytywne, takie jak ciekawy wykład lub zajęcia, a także normalny tok zajęć, gdy wykładowca wyjaśnia zagadnienie. Zainteresowanie i zaangażowanie w zajęcia sprawia, że student uczestniczy w tych zajęciach skupiony, w ciszy. Również wykładowca budzący respekt lub zainteresowanie może wpływać na to, że zajęcia przebiegaja w ciszy.

\subsection{Sytuacje generujące milczenie}

W odniesieniu do oceny własnego milczenia studenci zdecydowanie najczęściej wymieniali brak wystarczającej wiedzy, by zabrać głos lub udzielić odpowiedzi na pytanie oraz, co się z tym wiąże, brak przygotowania do zajęć. Ponadto o niezabieraniu głosu decyduje brak zdania na omawiany temat, co pojawia się szczególnie często w przypadku dyskusji czy debat. Stosunkowo nieliczna grupa osób wskazała na brak środków językowych, by móc sformułować wypowiedź. W przypadku milczenia kolektywnego, o którym była mowa powyżej, ciszę najczęściej kojarzono z warunkami do pracy, a dopiero w drugiej kolejności z brakiem wiedzy, natomiast w przypadku ciszy indywidualnej, czyli milczenia poszczególnych jednostek, najczęstsza przyczyna ciszy ma charakter intelektualny i wynika z deficytu wiedzy. 
Następny czynnik ma charakter afektywny i obejmuje takie stany jak brak pewności, co do poprawności odpowiedzi, strach przed popełnieniem błędu, strach przed krytyką wykładowcy i innych studentów, stres. Czynnik afektywny w odniesieniu do milczenia indywidualnego pojawiał się znacznie częściej niż w przypadku milczenia kolektywnego.

Wymienione wyżej czynniki intelektualne i afektywne przynależą bezpośrednio do osób, które o nich pisza. W ankietach wymieniano także czynniki o charakterze zewnętrznym w stosunku do studenta. Po pierwsze, tematyka zajęć w dużym stopniu może wpływać na udział w zajęciach lub milczenie. Nie tylko stopień atrakcyjności tematu wpływa na partycypację studentów, ale również inne jego aspekty: nielubiany temat zajęć, kontrowersyjne tematy (np. o Bogu, homoseksualizmie), tematy z różnych względów nieodpowiadające, tematy zbyt łatwe, tematy zbyt osobiste/drażliwe. Ponadto sposób formułowania pytań pobudza do mówienia, lub przeciwnie, do milczenia. Kolejny czynnik ma charakter fizjologiczny i został wymieniony niespodziewanie często - obejmując zmęczenie, niewyspanie, a nawet głód. Chęć do mówienia mogą blokować też inne osoby, studenci, którzy ciągle mówią lub przerywają wypowiedź, także niemiły wykładowca. Na werbalną partycypację w zajęciach ma wpływ także wielkość grupy, gdyż trudniej odzywać się w grupie dużej. Ponadto niektórzy respondenci twierdza, że nie mają ochoty na mówienie, nie odzywają się, gdy nie jest to konieczne lub, gdy nie sa proszone. Inne uważają, że milczenie wynika z ich osobowości, nigdy nie wypowiadają się, wolą słuchać, uważają, że nic ciekawego nie potrafia powiedzieć. Na wstrzymywanie się od mówienia na zajęciach wpływa także zła atmosfera, niedosłyszenie lub niezrozumienie pytania, fakt wcześniejszego częstego zabierania głosu. Jak się okazuje, także zalegająca cisza paraliżuje niektóre osoby przed zabraniem głosu.

\subsection{Wpływ ciszy i milczenia na studentów i zajęcia}

Wpływ ciszy i milczenia na uczących się zależy, między innymi, od tego, czy jest to cisza/milczenie pozytywne, czy negatywne. Odpowiednio będzie się więc kształtowała percepcja ciszy/milczenia oraz ich znaczenie w procesie uczenia się i nauczania.

W wielu przypadkach cisza jest zjawiskiem pożądanym. Przede wszystkim jest potrzebna podczas wykonywania zadań wymagających koncentracji, takich jak słuchanie, czytanie, rozwiązywanie zadań, pisanie testu. Ponadto cisza stwarza korzystne warunki do nauki w przypadku nowego i trudnego materiału. Cisza jest także potrzebna, gdy udzielenie odpowiedzi na postawione pytanie wymaga zastanowienia. Jeśli w takich sytuacjach na zajęciach panuje cisza, jej wpływ oceniany jest pozytywnie. Respondenci wymienili szereg korzystnych efektów: cisza pomaga w koncentracji, ułatwia naukę, umożliwia niezakłócone usłyszenie wypowiedzi innych, daje czas na zastanowienie przed udzieleniem odpowiedzi. Ponadto cisza zdaniem studentów relaksuje, uspokaja, pozwala odpocząć, stwarza dobre, spokojne warunki do nauki. Cisza ułatwia samodzielną pracę, gdyż nie jest się rozpra- 
szanym przez innych. Dzięki temu można lepiej myśleć i w konsekwencji uzyskać lepsze rezultaty w nauce. Można sądzić, że taki pozytywny wpływ wyzwala cisza w jakiś sposób zainicjowana przez nauczyciela poprzez dobór zadań oraz podtrzymana przez uczących się w celu realizacji tych zadań. Nie jest to więc cisza konwersacyjna, ale raczej tekstowa, lub ujmując szerzej, zadaniowa.

Jednak w zdecydowanej większości respondenci w ocenie ciszy odnieśli się do ciszy niepożądanej, oceniając tym samym jej wpływ na uczestników zajęć i zajęcia w sposób negatywny. Oceny te przebiegają w kategorii emocjonalnej, intelektualnej oraz międzyludzkiej. Kategoria emocjonalna obejmuje takie stany jak skrępowanie, napięcie, stres, zniechęcenie, zdenerwowanie, zawstydzenie, onieśmielenie, strach, zdenerwowanie, zniecierpliwienie, obniżenie samooceny, znudzenie, demotywacja, niepewność. W kategorii intelektualnej znajdą się takie konsekwencje jak rozkojarzenie, nieprzyswajanie wiedzy, zahamowanie rozwoju, nierozwijanie umiejętności językowych. Skutkiem milczenia mogą być zaburzone relacje między uczącym a uczącymi się, brak kontaktu, również brak kontaktu wzrokowego na zajęciach z innymi ich uczestnikami, z jednej strony budowanie oczekiwań wobec innych osób, z drugiej narastająca cisza może demotywować do współpracy. Poza tym milczenie studentów w sytuacji oczekiwanej interakcji utrudnia prowadzenie zajęć i ogólnie obniża ich poziom.

Pewne rodzaje ciszy są szczególnie źle postrzegane i wpływają, w odczuciu respondentów, bardzo niekorzystnie na przebieg zajęć. Do takich sytuacji należą: brak zrozumienia tematu i „chowanie” się wówczas w ciszę, stawianie przez wykładowcę pytań, na które nikt nie zna odpowiedzi lub nie chce odpowiedzieć. Kłopotliwa jest również cisza wynikająca z braku zainteresowania tematem, cisza przedłużająca się, gdy studenci nie znają odpowiedzi, a prowadzący wyczekuje, by ją usłyszeć, cisza wywołująca zdenerwowanie wykładowcy lub powstała w wyniku zdenerwowania nauczyciela, cisza, która powstaje z obawy przed krytycznym komentarzem prowadzącego, cisza wywołana obawą przed kompromitacją. Jeden z respondentów podsumował krótko wpływ ciszy (w domyśle - negatywnej) na swoje odczucia: „Nie lubię ciszy, cisza stresuje”.

\section{Dyskusja}

Przedstawione powyżej wyniki badania, zebrane na podstawie odpowiedzi studentów na pytania dotyczące ich percepcji ciszy i milczenia na zajęciach z języka angielskiego ukazuja ciszę i milczenie jako konstrukty o znaczeniu pozytywnym i negatywnym, w zależności od ich genezy. Wnioskować można, że w trakcie zajęć w miarę oczywiste jest znaczenie ciszy o charakterze pozytywnym, kiedy to zazwyczaj świadczy ona o zaangażowaniu uczących się w wykonanie zadań lub jest nastawiona na aktywne słuchanie wykładowcy, ewentualnie innych uczestników zajęć. W przypadku ciszy odbieranej jako zjawisko negatywne zakres znaczeniowy wydaje się w kontekście tego badania większy, tym samym może być trudniejszy w interpretacji. Z pewnością jednak i w jednym i w drugim przypad- 
ku cisza i milczenie komunikują odbiorcy znaczenia, które się w tych dwóch konstruktach kryją. Jeśli pokusimy się o sformułowanie komunikatów ciszy negatywnej w oparciu o wyniki tego badania, to przykładowo mogą one brzmieć następująco: nie posiadam takiej wiedzy, nie potrafię się wypowiedzieć, nie rozumiem, jestem zmęczony, nie mam odwagi, te zajęcia są nudne, nie będę wypowiadać się na takie tematy, w takiej atmosferze trudno pracować, nie chcę, by mnie krytykowano, nie zależy mi, nie podoba mi się ten styl zajęć, nie należę do tych, którzy lubią mówić.

Te znaczenia w pewnej mierze są zgodne z wynikami wspomnianego już badania przeprowadzonego przez Tatar (2005) wśród nieanglojęzycznych studentów amerykańskiego uniwersytetu. W obecnym badaniu, wydaje się, że możemy dostrzec jeszcze więcej znaczeń ciszy i milczenia w kontekście nauczania formalnego w klasie. Jeśli powrócimy w tym miejscu do listy znaczeń ciszy zaproponowanej przez Johannensena (1974), to zobaczymy, że w odniesieniu do klasy szkolnej może zostać ona poszerzona o kolejne znaczenia, m.in.: (1) Uczeń jest zainteresowany tematem. (2) Uczeń jest skupiony na wykonywaniu zadania. (3) Uczeń respektuje innych. (4) Uczeń nie ma nic do powiedzenia. (5) Uczeń nie potrafi się wypowiadać. (6) Uczeń boi się wypowiadać. (7) Uczeń nie jest zainteresowany tematem. (8) Inne osoby nie pozwalają się uczniowi wypowiadać. (9) Zajęcia nie sprzyjają wypowiadaniu się. (10) Uczeń nie czuje się dostatecznie dobrze, by zabierać głos. Jednakże dokonując interpretacji ciszy i milczenia należy zachować ostrożność, gdyż jak zauważa Saville-Troike (1985), ich znaczenia mogą być niejednoznaczne i łatwo ulegać błędnej ocenie i interpretacji.

Fakt ten nie jest bez konsekwencji dla osoby nauczającej, od której oczekuje się właściwego, sprzyjającego rozwojowi uczniów, kierowania procesem uczenia się. Po pierwsze, konieczna jest świadomość różnorodności znaczeń ciszy i milczenia i umiejętność odczytywania komunikatów, które uczący się wysyłaja poprzez powstrzymanie się od mówienia. Po drugie, pożądana jest zdolność właściwego „zarządzania” ciszą i/lub milczeniem. Cisza powinna być zapewniona w tych sytuacjach, gdy jest niezbędna do właściwego wypełnienia zadań lekcyjnych. Co natomiast można uczynić, w sytuacji, gdy nauczyciel oczekuje wypowiedzi uczniów, a napotyka ciszę? Gdy oczekuje z ich strony pytań, dyskusji, argumentacji, a studenci milczą? Wiele zależy od konkretnego kontekstu sytuacyjnego. W pewnym sensie mamy do czynienia z problemem natury etycznej. Jak pisze Petress (2001), niechęć studentów do partycypowania w zajęciach z jednej strony pozbawia ich możliwości dzielenia się swoją wiedzą z innymi, $z$ drugiej strony pozbawia nauczyciela i innych studentów możliwości korzystania z wiedzy, którą dysponuje „milczący” student.

Jak już wiemy z opisanego badania, przyczyn milczenia może być wiele, dlatego zatrzymam się tutaj nad dwoma tylko, jedna z nich to obawa, lęk przed mówieniem, druga natomiast to problemy z wypowiadaniem się w związku $\mathrm{z}$ brakiem dostatecznych środków wyrazu. Lęk przed mówieniem (ang. communication apprehension) ogólnie rozumiany jest jako pewien poziom indywidualnego 
strachu lub lęku związanego z realną lub antycypowaną komunikacją z innymi osobami (McCroskey, 1984: 13), przy czym jest to doznanie znacznie poważniejsze niż zwykła trema, czasem prowadzące wręcz do objawów natury fizjologicznej, takich jak ból brzucha, zaczerwienienie, drżenie rąk. Uczeń mający tego typu problemy będzie również miał trudności z zastosowaniem i transferem wiadomości i umiejętności, które posiada (Petress, 2001). Pewną pomocą może służyć w takiej sytuacji rozwiązanie proponowane przez Petressa, mianowicie prawdziwy, etyczny dialog, który umożliwia i zachęca wszystkich uczestników wydarzenia komunikacyjnego do uczestnictwa w tym wydarzeniu poprzez mówienie i słuchanie innych. Zaangażowanie w komunikację międzyosobową wymaga zgody respektowania drugiej osoby poprzez nie pomniejszanie jej wkładu do rozmowy, nie ignorowanie prezentowanych idei, nie ignorowanie osoby. Nauczyciele moga stwarzać warunki do takiego dialogicznego podejścia do komunikacji w klasie poprzez proponowanie różnych form komunikacji, takich jak dyskusja, debata, analiza, praca w grupach, burza mózgów, poprzez konstruowanie sytuacji, w których każdy chce partycypować, poprzez cierpliwą postawę wobec osób mających problemy z wypowiadaniem się, nie zmuszanie ich do udziału w zajęciach, poprzez zwracanie uwagi na to, co mówią te osoby, parafrazowanie, rozszerzanie itp., zachęcanie do wzajemnego odwoływania się do wypowiedzi osób w grupie, by nadać tym wypowiedziom ważne znaczenie (Petress, 2001). W tym miejscu przejdę do drugiej z możliwych przyczyn nie wypowiadania się na zajęciach, mianowicie chodzi o niedostateczne środki wyrazu, będące w dyspozycji uczących się. W przypadku nauki języka obcego ten element, choć przez studentów biorących udział w badaniu nie był nadmiernie eksponowany, wydaje się mieć pierwszorzędne znaczenie i być może ukrywał się również w innych stwierdzeniach dotyczących właśnie lęku przed mówieniem. Trudno się wypowiadać nie posiadając odpowiednich środków językowych, zwłaszcza, że nie każdy ma wystarczająco rozwinięte strategie komunikacyjne. Dlatego w kontekście nauki języka obcego do sugestii Petressa na temat stwarzania warunków stosownych dla prowadzenia zajęć opartych na komunikacji dialogicznej należy dodać odpowiednie przygotowanie studentów pod względem językowym, przygotowanie potrzebnej bazy językowej dla danej sytuacji komunikacyjnej oraz zapoznanie ich z możliwymi strategiami komunikacyjnymi.

\section{Podsumowanie}

W artykule tym została podjęta próba przedstawienia problemu ciszy i milczenia na zajęciach z praktycznej nauki języka obcego w oparciu o dotychczasowe omówienia problemu w literaturze przedmiotu oraz przeprowadzone badanie własne. Na podstawie danych otrzymanych w badaniu można było uzyskać wgląd w to, jak postrzegane są cisza i milczenie na zajęciach języka angielskiego. Otrzymaliśmy obraz bogaty znaczeniowo od ciszy pozytywnej, wspierajaccej proces uczenia się do ciszy i milczenia negatywnego, hamującego wypowiedzi 
studentów. W jaki sposób zostaną cisza i milczenie wkomponowane w proces nauczania/uczenia się zależy w dużej mierze od nauczającego, ale także od wszystkich członków grupy. Rolą nauczyciela jest minimalizowanie ciszy negatywnej i jej skutków oraz dobre wykorzystanie ciszy pozytywnej. Należy jednak również uwzględnić cechy osobowościowe studentów, by nie wymuszać na nich mówienia, jeśli jest to wbrew ich ogólnemu stylowi uczenia się.

\section{BIBLIOGRAFIA}

Bilmes, J. 1994. „Constituting silence: life in the world of total meaning”. [w:] Semiotica 98: 73-87.

Bruneau, T. J. 1973. „Communicative silences: forms and functions”. [w:] The Journal of Communication 23: 17-46.

Ellis, R. 1999. „Theoretical perspectives on interaction and language learning”.

[w: Ellis, R. (red.). Learning a second language through interaction. Amsterdam: John Benjamins. 3-32.

Ephratt, M. 2008. ,The functions of silence”. [w:] Journal of Pragmatics 40: 1909-1938.

Ephratt, M. 2011. „Linguistic, paralinguistic and extralinguistic speech and silence". [w:] Journal of Pragmatics 43: 2286-2307.

Harumi, S. 2011. „Classroom silence: Voices from Japanese EFL learners”. [w:] ELT Journal 65: 260-269.

Heydon, G. 2011. „Civil right or social privilage? A discourse analytic response to a legal problem". [w:] Journal of Pragmatics 43: 2308-2316.

Jaworski, A. 1997. „Introduction”. [w:] Jaworski, A. (red.). Silence. Interdisciplinary perspectives. Berlin: Mouton de Gruyter. 39-61.

Jaworski, A. i Sachdev, I. 1998. „Beliefs about silence in the classroom”. [w:] Language and Education 12: 273-292.

Jaworski, A. i Sachdev, I. 2004. ,'Teachers' beliefs about students' talk and silence: Constructing academic success and failure through metapragmatic comments". [w:] Jaworski, A., Coupland, A. N. i Galasiński, D. (red.). Metalanguage. Social and ideological perspectives. Berlin: Mouton de Gruyter. 227-243.

Jensen, V. J. 1973. „Comminicative functions of silence”. [w:] ETCA Review of General Semantics 30. 249-257.

Johannesen, R. L. 1974. „The functions of silence”. [w:] Western Speech 38: 25-35.

Kurzon, D. 1998. Discourse of silence. Amsterdam: John Benjamins Publishing.

Kurzon, D. 2007. „'Towards a typology of silence”. [w:] Journal of Pragmatics 39: 1673-1688.

McCroskey, J. C. 1984. „The communication apprehension perspective”. [w:] Daly, J. i McCroskey, J. C. (red.). Avoiding communication: Silence, reticence, and communication apprehension. Beverly Hills, C.A. Sage Publications. 13-38.

Malandro, L. i Barker, L. 1983. Nonverbal communication. Reading, MA: Addison-Wesley.

Nakane, I. 2007. Silence in intercultural communication: Perceptions and performance. Amsterdam: John Benjamins Publishing. 
Nęcki, Z. 1996. Komunikacja międzyludzłka. Kraków: Wydawnictwo Profesjonalnej Szkoły Biznesu.

Ollin, R. 2008. „Silent pedagogy and rethinking classroom practice: structuring teaching through silence rather than talk". [w:] Cambridge Journal of Education 38: 265-280.

Petress, K. 2001. „The ethics of student classroom silence”. [w:] Journal of Instructional Psychology 28: 104-107.

Seville-Troike, M. 1985. „The place of silence in an integrated theory of communication". [w:] Tannen, D. i Seville-Troike, M. (red.). Perspectives on silence. Norwood, NJ. Ablex Publishing Corporation. 3-18.

Sobkowiak, W. 1997. „Silence and the markedness theory”. w: Jaworski, A. (red.). Silence. Interdisciplinary perspectives. Berlin: Mouton de Gruyter. 39-61.

Tatar, S. 2005. „Why keep silent? The classroom participation experiences of nonnative-English-speaking students". [w:] Language and Intercultural Communication 5: 284-293.

Walsh, S. 2002. „Construction or obstruction: teacher talk and learner involvement in the EFL classroom". [w:] Language Teaching Research 6: 3-23.

Walsh, S. 2006. Investigating classroom discourse. Abington: Routledge. 